\author{
Jérôme Blanc, Ludovic Desmedt, «In search of a 'crude fancy of \\ childhood': deconstructing mercantilism », Cambridge Journal of \\ Economics, Oxford University Press (OUP), 2014, 38 (3), pp.585-604.
}

\title{
In Search of a 'Crude Fancy of Childhood': Deconstructing Mercantilism
}

\begin{abstract}
"Once upon a time everyone believed that national prosperity depended upon the accumulation of gold bullion resulting from a favourable balance of payments. A man called Adam Smith denied this and later another man called David Ricardo actually proved that free trade and leaving the balance of payments to take care of itself produced the best of all possible worlds. Thereafter, every schoolboy could expose the fallacies of "mercantilism". Members of the German Historical School protested that the mercantilists had been misunderstood, but in the 1930s the big guns of international scholarship went one better than the schoolboy: the mercantilists were not only poor theorists but also poor historians, writing in almost total ignorance of the economies in which they lived."
\end{abstract}

Mark Blaug, 1964, p. 111

\begin{abstract}
This paper argues against the unity of 'mercantilism', refuting a rational reconstruction that underestimates both the diversity of early modern European economists and their writings, and the depth of their analyses. Beginning with a brief examination of the origins of 'mercantilism' and the evolution of perceptions of it, we examine in the first section the various readings proposed of 'mercantilist' writings (classical 'reconstruction', German historical school, then contemporary work). The 'deconstruction' undertaken here does not aim to demonstrate that pre-classical writings were devoid of any conceptualization or internal coherence. However, contemporary readers must make some effort to grasp the concepts used and engage with the proposals made. To this end it might be useful to propose an initial classification of authors based on their social position. The paper identifies different categories of writers and proposes new combinations of authors reflecting the range of economic, and especially monetary, thinking of the period, with reference to the position of those authors relative to the spheres of government in Europe (second section). This categorization takes account of the social position of the authors, so as to identify any implications it might have for their concerns and their proposals. We first identify three categories of writers who are generally outside those spheres (late scholastics, economic philosophers and pamphleteers); then two categories of 'insiders' (officers of the mint and treasury administrators). The closeness of authors to the regime significantly influenced their writings.
\end{abstract}




\section{Introduction $^{1}$}

In the simplistic view of the history of economic ideas, 'mercantilists' are portrayed as 'fools', 'cranks', or are suspected of using 'an empty box when considered as a collection of ideas'. They are commonly said to have held 'pre-scientific' conceptions (Stigler, 1983) described as 'one of the crude fancies of childhood' (Mill, 1848-1871, vol. 1, p.4), to have been prisoners of obsolete patterns of thought, and to have inspired misguided if not downright dangerous economic policies. Ever since the classical economists interpretation of it, and despite the cyclical recurrence of 'neo-mercantilist' ideas (Hettne, 1993), mercantilist economic literature has borne a stigma. More especially, certain more circumspect contemporary works notwithstanding, the idea that sixteenth- to eighteenth-century economic writings confused money and wealth still thrives today.

'Mercantilism' is an ex-post classification, an intellectual reconstruction postdating the long period during which mercantilism was supposedly propounded. The first use of the label 'mercantilism' dates to the second half of the eighteenth century with the French physiocrats and Adam Smith. Ever since then, the general view that this was a coherent system endorsed by thinkers of the time has been widely defended. Like any conceptual reconstruction, the invention of mercantilism suffers from a prejudicial bias, so much so that mercantilism can be construed as a myth constructed on a solid ideological foundation and bound up with Whig history. ${ }^{3}$ 'Mercantilism' is often used to characterize two sets of propositions, theoretical and political, both being frequently intermingled, with the former presumably fuelling the latter. This paper does not question the existence of a mercantile economy between the sixteenth and eighteenth centuries: the Navigation Acts, Colbertism or Spanish bullionism are hard historical fact. ${ }^{4}$ It contests that pre-classical writers between the sixteenth and the early eighteenth century rallied to two principal ideas:

- a chrysohedonist assumption: mercantilists confused wealth with precious metals, sometimes more specifically with those precious metals that are minted or could be minted $^{5}$

- a bullionist assumption: mercantilists defended the favourable balance of trade doctrine (synonymous with protectionism) about attracting foreign precious metals ${ }^{6}$.

\footnotetext{
${ }^{1}$ This article is related to the preparation of a collective work, forthcoming in French, on the history of monetary ideas, which will cover the period 1500-1776. We owe much to the contributors to the book, whose works allowed us to work on the transversal viewpoint that appears in this text: respectively, L. Baeck, N. Bond, J. Cartelier, J. L. Cardoso, L. Gillard, G. Jacoud, C. de Lozanne Jefferies, A. Murphy, A. Ögren, S. Pamuk, D. Raskov, L. Runefelt, J. T. Ravix, A. Tiran, and C. Wennerlind. We would like to thank Isabelle Laudier and the Institut Caisse des Depots et Consignations pour la recherche for supporting the project.

The participants of the ESHET conference in Porto and the AHE conference in Bristol made the first remarks on preliminary versions of this text. We acknowledge very useful comments by the anonymous referees of this journal. We claim of course entire responsibility for the ideas developed in this text.

${ }^{2}$ Respectively Gerschenkron (1969, p. 2), speaking of Viner ('fools'); Blaug, 1964 ('monetary cranks'); Ekelund and Tollison, 1997, p. 15 ('empty box').

3 'Paradoxically because a particular interpretation of the past was so important to the Whigs, they could not afford to pursue open-ended historical investigation. [...] While the cosmetic of ideology hid the true face of English politics, it would be wrong to conclude that the myths of mercantilism and Whig history were adopted for their beauty.' Appleby, 1978a, p. 275. See also Skinner, 1965.

${ }^{4}$ On these policies, see Ekelund and Tollison, 1997, challenged by Rashid, 1993.

5 'The most common criticism of the mercantilists is that they regarded the precious metals as the sole constituents of the wealth of the nation. Adam Smith made this charge a central feature of his criticism of the mercantilist doctrines...', Viner, 1930a, p.264

${ }^{6}$ In a recent book, we can still find the following idea: 'the mercantilists' desire to maximise the gold and silver within a country took the form of attempts by the government to create a favorable balance of trade', Hunt, Lautzenheiser, 2011, p.20.
} 
Mercantilism, judging from the various readings of it, seems to focus on the two interconnected fields of monetary matters and political issues. This paper examines in what way many of the economic publications between the sixteenth and eighteenth centuries are structured along these two lines in a different way from what has too often been assumed. This paper proposes to deconstruct mercantilism as a way to reappraise it. This entails trying to restore the diversity of economic analyses that were current in Europe around the seventeenth century. We aim to show that the ideas of the time (through monetary discourse) were much more varied and open to dispute (if not complex in their actual development) than the uniformity of the policies of the time would suggest. This deconstruction does not lead to the claim that there was no conceptualization or no theorizing, but that there were several strands of thought involved.

In recent decades much work has been done on this period of history, furthering our understanding of certain economists and certain national contexts (especially for England) but also bringing to light (again) forgotten commentators or writings. However, two frequent biases remain: first, recent commentators on mercantilism still focus on the writings of a small set of authors (Mun, Petty, Locke, Davenant); second, they still focus largely on England. ${ }^{7}$ When trying to capture the common conceptions of the time, any analysis that narrows the diversity of economic discourse in Europe to just one set of English authors (most of them fellow travelers of political arithmeticians), is hardly satisfactory. Quite the contrary, scholars need to widen the scope and encompass a much broader range of writings. This paper draws on a forthcoming collective work on the history of monetary ideas in Europe from Copernicus to Smith, thereby extending the examination of mercantilism to mainland Europe, for matters of the balance of trade, debasement, exchange, and so on were of concern to all of the sovereign powers of early modern Europe. ${ }^{8}$ English-speaking economists were not the only ones to engage with these issues and it would be wrong to overlook their French, German, Spanish, Italian and Swedish counterparts. Plainly a paper like this cannot discuss every author, current and country at length. The present investigation is therefore extensive rather than intensive in that it seeks to include economists from different countries rather than investigate any single one of them; it looks to provide a panorama rather than a monograph; it aims to construct a typology rather than to make case studies.

The paper begins with a brief examination of the origins of 'mercantilism' and the evolution of the perception of it from the late eighteenth century to the present day (section 1). The classical school engaged in a rational reconstruction (Blaug, 2001), focusing on what it identified as the monetary fallacies of mercantilism (1.1). The German historical school underscored the question of power (1.2). Although the two schools have different perspectives of mercantilism, the two are interconnected, since monetary questions are closely bound up with the science of government. The wealth of debate since the 1930s has led to a dismissal of the view that the pre-classical era was monolithic (1.3). The paper then identifies various categories of writers and proposes new combinations of authors as an illustration of the diversity of the economic, and especially monetary, thought of the period. Five such categories are identified (section 2), on the strength of two criteria: their conceptions of money and their closeness to the regime. This categorization takes account of the social position of the authors, so as to identify any implications it might have for their concerns and their proposals. Their proximity to the spheres of political power influences their views. We identify three categories of writers who are

This is especially obvious in English-language books, with, for example, Appleby (1978b), Coats (1992) and Finkelstein (2000). See below, section 1.3. In English-language texts, exceptions multiplied in more recent years, with for example Hutchison (1988), Baeck (1994) and Perrotta (2004). Magnusson (1993) gets out of England mostly because of Perrota's chapter. Non-English scholars are naturally keener to study non-English writings of early modern Europe.

8 'Spain, France, England, the Netherlands, and the Lands of the Empire faced a common set of problems [...] with a common pool of ideas', Finkestein, 2000, p. 4. 
generally outside those spheres (2.1): late scholastics (2.1.1), economic philosophers and polymaths (2.1.2) and pamphleteers (2.1.3), and two categories of 'insiders' (2.2): officers of the mint and regular advisers on money matters (2.2.1) and treasury administrators (tax officials, regular advisers on finance and ministers) (2.2.2). While the categories are not watertight, they are useful for isolating orientations characteristic of a particular group. For example, merchants who drafted pamphlets, scholastic writers, or those affiliated to the treasury were to develop widely differing view of credit and of interest rates. Hence, this paper contests the predominance of the 'mercantilist' doctrine by showing the diversity of thinking and of the positions held by a wide range of authors. Its main findings are that proximity of commentators to government significantly affected their writings on, say, the sovereign's power over money, or on price rises.

\section{Mercantilism as a reconstructed doctrine: the case of money and the role of the state}

Mark Blaug (2001) borrows terms from Richard Rorty in identifying two alternative paths that can be travelled by historians of economic thought, contrasting 'historical reconstruction' with 'rational reconstruction'. 'Historical reconstruction' attempts to understand the intellectual context in which a discourse arises, delving into the texts in an effort to present ideas as they emerged in their day. 'Rational reconstruction' views economics as a cumulative science, with its dead-ends and errors, and tries to express past ideas in present-day terms.

Rational reconstruction is akin to what is commonly labelled as the 'Whig interpretation of history' (see Kurz, 2006). Economic writers of early modern Europe, from the sixteenth century to the first half of the eighteenth century, were considered from this Whig viewpoint, once Quesnay and, a little later, Smith had critically appraised them and invented the notion of 'mercantile system'. More than two centuries later, Stigler's Nobel lecture presented a blatantly Whiggish view of mercantilism, taking it as an illustration of 'prescientific economics', denouncing the lack of any cumulative improvement in mercantilist doctrines and their nature of being 'almost always briefs for special interests' (Stigler, 1983, p. 531). Economics was to escape from this poor intellectual (and political) tradition by virtue of the major 'advance' that classical economics represented for the discipline. Rational and historical reconstructions alike led to the forging of a mercantilist doctrine, whether it was considered coherent or not. That doctrine was shaped to fit the theoretical framework and purpose of every mainstream, undercurrent, or individual commentator, from the classical school down to Heckscher's book (1931), by way of the German historical school. However, after the 1930s, such a unifying view of 'mercantilism' came in for criticism. Two reconstructions are of interest to us, since they were influential and since they make their points about specific features of mercantilism: first, rational reconstructions exposing how 'pre-scientific' reasoning about money was necessarily and successfully swept aside by theoretical progress; second, historical reconstruction by the German historical school reassessing those writings and emphasizing 'the reason of state'.

\subsection{Monetary fallacies: 'pre-scientific' reasoning through the lens of rational reconstructions}

The classical school took the path of rationally reconstructing the 'mercantilist' doctrine and emphasized a number of its critical features, including money.

Although the physiocrats had already seriously criticized the 'system of merchants' (Quesnay, 1757; Mirabeau, 1763) and even the 'absurd inconsistency of the mercantile system' (Mirabeau, 1763, p. 329), it was Adam Smith who was the leading proponent of the idea that mercantilism was a flawed, but quite homogeneous set of doctrines. This point was already developed in his Lectures on Jurisprudence, in which he stated that 'The wea[1]th of the kingdom has by allmost 
authors after Mun been considered as consisting in the gold and silver in it'. 'A few years later, the longest chapter of his Wealth of Nations decried what he called the 'mercantile system'. The rock on which this system was supposedly built was the chrysohedonist maxim that money (and, more specifically, precious metals) is wealth. Smith saw this as a misunderstanding: 'That wealth consists in money, or in gold and silver, is a popular notion which naturally arises from the double function of money, as the instrument of commerce, and as the measure of value' (Smith, 1776, T.I., p. 429). By way of example, he cited Locke, who could be seen as maintaining such a confusion. Smith considered that practices such as bullionism (with its prohibition on exporting currency) and the obsession with a trade surplus were the logical outcome of this idea. While criticizing mercantilism, Smith was impressed by Mun's England's Treasure by Forraign Trade, although he dismissed some of its arguments. In Smith's writings, the doctrine of the 'mercantile system' is assimilated to certain legal and commercial practices (tariffs, retaliation, monopolies), which were much more uniform than the writings on which they were supposedly based.

Similarly, J. S. Mill opened his Principles of Political Economy by criticizing the 'system': '[...] the doctrine that money is synonymous with wealth [...] looks like one of the crude fancies of childhood' (Mill, 1848-1871, vol.1, p. 4). To its proponents, classical economics was a grown-up theory, a mature doctrine. As Judges states, 'The English economists [...] viewed the mercantile system as an agglomeration of commercial interferences fortified by a monetary fallacy which was itself based upon a misunderstanding of the real nature of international exchanges' (Judges, 1939, p.55).

\subsection{The German historical school's emphasis on 'reason of state'}

A second critical feature of 'mercantilism' was the doctrine of generalized state intervention in economic matters. This view emerged as a defining point of the term itself for the physiocrats and the classical liberal school.

The German historical school reconstructed mercantilism around this idea in particular. Their approach associated the economic strengthening of the nation-state with its political construction. In this perspective, Schmoller claimed that mercantilism arose at a time in Western development when economic concerns were subordinate to political ones. He stated that mercantilism 'in its innermost kernel [...] is nothing but state making-not state making in a narrow sense, but state making and national-economy-making at the same time' (Schmoller, 1897, p. 69). This meant that 'the essence of the system lies not in some doctrine of money, or of the balance of trade; not in tariff barriers, protective duties, or navigation laws; but in something far greater:- namely, in the total transformation of society and its organisation, as well as of the state and its institutions, in the replacing of a local and territorial economic policy by that of the national state'. If money is to be considered, it is thus not in terms of metal but of its 'active circulation [...] especially within the state itself (Schmoller, 1897, ibid.).

The German historical school built its reasoning on the idea that if mercantilist policies had been adopted, they were necessarily underpinned by a coherent body of theoretical discourse. Later, Cunningham, studying Englishmen's growing national consciousness, assimilated plenty with power and ascribed a central role to the balance of trade doctrine. He claimed that "This doctrine of the balance of trade obtained general acceptance in the earlier part of the seventeenth century, and exercized a considerable influence on legislation' (Cunningham, 1903, T.I., p. 177). Mercantilism arose as a historical necessity, when European nations were rising, transcending their specific

\footnotetext{
${ }^{9}$ He added: 'In his book called Englands [Treasure] by Foreign Trade, [Mun] endeavours to shew [that] the balance of trade is the only thing which can support England, as by this means gold and silver are brought into the kingdom, and in these alone he says the wea[l]th of the kingdom can consists as they alone are not perishable. On this doctrine of his, which however foolish has been adopted by all suceeding writers, these laws have been founded.' Smith, 1762-1763, v. 75-76, p. 300
} 
interests. However, although Schmoller defended the theory that supposedly underpinned mercantilist policies, he centred on the policies, as emphasized by Sombart (Tamura, 2001).

For Schmoller, the development of national territories was implemented and controlled by the state: an apparatus of administration, customs, colonial conquest, and so on was developed. Among these phenomena, the minting of coins was given paramount importance: in the numerous pages on the formation of nation-states, Schmoller never cited the networks of bills of exchange or of financial dealings among merchants. The economy of the mercantilist period was dominated by the state and apparently had little to do with the financial and monetary ingenuity of merchants. The received wisdom was that unification resulted from the circulation of coins involved in the development of public finance (see Backhaus, 2004). Monetary and fiscal policies were closely connected, seigniorage being an important source of state revenue. The preeminence of political philosophers like Bodin, Locke and Pufendorf in the mainstream of economic thought of their nations in that period seems to strengthen this view. In the struggle among elites to control government institutions (see Root, 1994), philosophers could wield substantial influence.

\subsection{Was the 'unifying system' a unified system? Reassessments from the $1930 \mathrm{~s}$ onwards}

Important contributions about the pre-classical period were published during the $1930 \mathrm{~s}$, in the troubled context of the Great Depression. That period was later analysed by Karl Polanyi as the 'great transformation', i.e. a farewell to a market society due to the irrepressible reactions of societies against the utopia of a self-regulating market system that had tended to be implemented (Polanyi, 1944). The transformation included new forms of economic protection and state regulation. The period was amenable to a re-appraisal of strands of non-liberal thought and of policies liable to provide long-forgotten insights into the way the state could master the crisis and, more generally, regulate the economy. Mercantilist policies and doctrines were reassessed and, to some extent, rehabilitated.

The publication of Heckscher's magnum opus, soberly titled Mercantilism, renewed interest in the nature of mercantilist doctrines and above all in their applications. ${ }^{10}$ Shortly thereafter, Viner, Judges and also Keynes used this work to build their own demonstrations, which exhibited certain divergences. Heckscher studied mercantilist policy 'between the Middle Ages and the age of laissez-faire' (Heckscher, 1935, p. 20). His work leads to the idea that the common denominator of the literature of this period was a static vision of commercial and monetary relations as a zerosum game (the profits of some groups being the losses of others). Most actors seemed to have a general 'fear of goods' that prompted protectionism. ${ }^{11}$ Heckscher saw those policies as a 'unifying system'. As evidence of this, Heckscher wrote a 'revision' of his book in a short article: '[...] Mercantilism became not only a specific type of economic policy, but even more, a characteristic body of economic ideas' (Heckscher, 1936, p. 45). Ekelund and Tollison later argued that he placed 'excessive emphasis on the cohesiveness of mercantilism as an economic doctrine' (Ekelund and Tollison, 1997, p. 10).

At the same time, Viner, in his Study of international trade theory, tried to delineate the leading themes of English mercantilism. He focused on the balance of trade, his key-idea being that

\footnotetext{
${ }^{10}$ Heckscher's book was first published in Swedish in 1931, but it was very soon translated and published in German (1932) and in English (1935).

11 'As soon as the result of production, from the producer's standpoint, no longer consists in other goods but in money, then the money yield appears as the only aim of economic activity, other goods are then considered unwelcome since they are merely competing with one's own products for the monetary equivalent.' Heckscher, 1935, II, p. 138. Heaton writes: 'The mercantilist was willing to take the cash and let the commodity go; he preferred bullion to butter.' Heaton, 1937, p. 389.
} 
bullionist positions dominated: 'The mercantilists wanted an export surplus primarily because they wanted more bullion and because they saw that for a country without gold or silver mines a favourable balance of trade was the only means available to procure bullion' (Viner, 1937, p. 15). He pointed up the 'fallacies' embodied in the literature of the period (Viner, 1937, p. 109): regulation of trade, an identification (by some authors) of specie with wealth (chrysohedonism), and a concern about population growth. But to summarize, for Viner, 'mercantilism appeared as a variety of fallacies, a remarkable chapter in the history of human stupidity, as something done, as Erasmus used to say, a stultis apud stultos, by fools for fools' (Gerschenkron, 1969, p. 2). He nevertheless experienced difficulties in identifying 'mercantilism', because his readings showed that many authors departed from the supposed dogma. He even identified the prolegomena of the theory of the self-regulating mechanism of international specie distribution (Vanderlint, Gervaise before Hume): 'Stated briefly, the theory is that a country with a metallic currency will automatically get the amount of bullion it needs to maintain its prices at such a level relative to the prices prevailing abroad as to maintain an even balance between its exports and imports. Should more money than this happen to come into that country, its prices would rise relatively to those of other countries, its exports, consequently, would fall, and its imports increase' (Viner, 1930b, p.419). After Viner, the pre-classical period in England was generally divided between 'balance-of trade' and 'bullionist' doctrines. The latter defended the view that the country's stock of bullion should be maintained, while, for the former, the concern was to increase the stock of money. Hence, after 1620, mercantilist literature is supposed to have propounded strong arguments in favour of protectionist policies.

In 1936, the famous short note at the end of Keynes' General Theory was conceived as an attempt to rehabilitate mercantilist thought. Keynes took for granted the desire to increase the stock of money in circulation, and associated it with the promotion of investment. In a system where it was impossible to make changes in the rate of interest, the doctrine of an excess of exports over imports was fruitful, but as a means to ease the investment process. Therefore, 'the methods of the early pioneers of economic thinking in the sixteenth and seventeenth century may have attained to fragments of practical wisdom which the unrealistic abstractions of Ricardo first forgot and then obliterated' (Keynes, 1936, p. 340). Once again, the question of optimal policies was discussed. Keynes' optimistic statement was contested by Blaug for whom 'an increase of the stock of money [...] in a dominantly agrarian economy merely produce[s] inflation without leading to full employment. If this be accepted, it follows that most of Adam Smith's predecessors were "monetary cranks", not prescient Keynesians' (Blaug, 1964, p. 115).

From the 1930s onward, those reassessments of mercantilism were supplemented by a series of important studies uncovering authors and controversies, which showed the complexity of the whole period in terms of economic writings. Heckscher's 'unifying system' came to ressemble a ragbag of thoughts and authors ${ }^{12}$.

Already in the 1930s, Judges noted that for "an "ism" to be worthy of serious consideration [it] must offer a coherent doctrine, or at least a handful of settled principles' (Judges, 1939, p. 41). He was highly doubtful that mercantilism 'had a creed' and 'a priesthood dedicated to its service' (Judges, 1939, p. 42).

Schumpeter displayed an interest for 'mercantilism', emphasizing that it was rooted in 'a formative period in which there were no professional standards' (Schumpeter, 1954, p. 155), and treating it as pre-analytical thinking. However, he did acknowledge some remarkable

\footnotetext{
12 'Notwithstanding the great prestige of Eli F. Heckscher, I disagree with his statement that mercantilism strove toward unity. As a matter of fact, non-scholastic economics in the seventeenth and eighteenth centuries varied greatly from country to country. In my opinion, the name "mercantilism" is appropriate only for British economics during that period.', de Roover, 1955, pp.181-2. Heckscher's positions were discussed by Heaton (1937), Wilson (1957, 1967), Coleman $(1957,1969,1980)$, Herlitz (1964)...
} 
achievements by authors like Petty, Steuart and others and criticized 'that imaginary organon, "the mercantilist system" of traditional teaching' (Schumpeter, 1954, p. 335).

Some recent works have returned to this 'mercantilist' literature, with as their common ground, the restoration of a certain diversity and complexity of analysis. In his genealogy of civic bumanism, J.G.A. Pocock (1975) examines ideas developed by a few late seventeenth-century English writers (Davenant, Locke and Defoe). Similarly, Joyce Carol Appleby identifies in seventeenth-century English writings the birth of issues related to market mechanisms (Appleby, 1978b). She explicitly associates context and discourse: 'The material conditions of English life changed in the seventeenth century and prompted some participants to explain and justify, others to attack, the innovations introduced' (Appleby, 1978b, p. 22).

In his work on economic thought, Terence W. Hutchison (1988) underscores national specificities and divergences of views. His work is valuable in that it presents not just Englishspeaking but also Italian, German and French commentators. As he points out, 'pluralism ruled' (Hutchison, 1988, p.11). This paper adopts a similar approach, but focusing on writings dealing directly with monetary, financial and political issues. Mirowski (1989) developed the idea that there were two 'kinds of mercantilism', distinguishing between a 'balance-of-trade mercantilism' and a 'free-trade mercantilism'. The former took money as an index of value, the latter sought an intrinsic value. But Mirowski analysed the works of Misselden, Petty, Barbon and North only. Magnusson (1994) includes few insights into non-English writings.

More recently, Andrea Finkelstein (2000) traces the intellectual atmosphere of seventeenthcentury England from the writings of nine commentators (Malynes, Misselden, Mun Petty, Child, Locke, Barbon, Davenant and North), warning her readers that 'Even such a familiar label as mercantilism has been avoided until it can be reconstructed from the evidence offered by the nine writers discussed herein' (Finkelstein, 2000, p. 1).

With a greater focus on factual analysis, some writers have returned to the construction of a 'Fiscal-Military State' (Dickson, 1967; Brewer, 1989; O’Brien, 1988; Hont, 2005). They claim that the rise in military spending and the extension of conflict in the seventeenth and above all the eighteenth centuries pushed the fiscal question up the agenda of the time. This important issue informed the views of treasury officials, to which we shall return. The theoretical support to modern (commercial) state building during the 18th Century was analyzed by Hont (2005), through theories of trade and market competition in the international context. Though studying Pufendorf's thesis and influences, and going back to the aftermaths of the English Glorious Revolution, his view was mostly focused on English thought and analyzed 17th and 18th century thinking in the light of further theoretization.

There is therefore a line of contemporary critical analysis that seeks to capture the intellectual atmosphere of the period of interest to us. Analysing matters from the standpoint of a non-Whig historian of ideas (that is, by accrediting pre-classical analyses), one realizes that the corpus has swelled substantially over the course of time. Comparing the rare writers mentioned by Adam Smith (1776) with those discussed by Hecksher (1931) or Hutchison (1988), the scene is markedly busier. More writers, discoveries and rediscoveries, and an admittedly incomplete extension to countries outside of the Anglo-French core, make for a greater diversity of analysis. An attempt can therefore be made at drawing up a typology encompassing several European countries. 


\section{Categorizing early modern authors on economic and monetary} matters

By examining the economic writings of European commentators we can deconstruct mercantilism and identify separate categories of authors. When trying to understand the general position of commentators, the geopolitical context is extremely important, of course, especially when the unification of monetary circulation was at stake (for example, in the Holy Roman Empire), or simply because each country maintained specific relationships between sovereignty, money, merchants and society with its own specific laws, collective agreements and, more generally, institutions.

Nevertheless, the development of ideas was practically oriented by common issues, especially the problem of the debasement, enhancement and counterfeiting of coinage, the dramatic rise in prices in the late sixteenth century, the requirements of public finance, and the establishment of monetary sovereignty. Overall, monetary ideas were embedded in the context of a dualist metallic monetary system, which articulated an 'imaginary money' (a unit of account) defined by a metallic content and 'real money' (coins) made of metals. Moreover, there was a general shift in monetary thinking away from the problem of debasement of metallic currency and the stability of the unit of account during the sixteenth and seventeenth centuries and towards matters of bank credit and paper money, once most European countries had managed to secure long-term monetary stability, as was achieved in England after 1695 and France after $1726^{13}$. Such changes in monetary history can be coined a "monetary revolution" (Aglietta, 2002, pp. 41-42). A stable monetary system was a requirement to a sound system of credit, being itself a condition to the spreading of industrial capitalism. Authors like Steuart or Santis described these changes, unknown by Malynes or Lessius.

The development of ideas was also furthered by contacts among authors and the circulation of foreign writings: stays abroad fuelled discussions (Petty, Leibniz, Pufendorf, Law, Galiani, among many others, travelled extensively and sometimes lived abroad for some time; e.g. the Milanese merchant Basso wrote and advised in Castile). The development of printing since the Renaissance, the early use of Latin and subsequently of French as a lingua franca, together with translations into official languages in different kingdoms fostered the diffusion of ideas to wide audiences throughout Europe. In this respect, scholastic thought had an obvious influence on Roman Catholic Europe.

Hence, when defining categories of authors, it must be recognized that ideas were not developed exclusively in a specific national context, but that common issues and intellectual intercourse existed throughout Europe. Categories formed along the two main lines of power and money. The first broad categorization is determined by the social position of writers and especially by how close they were to the regime. The second broad categorization is dictated by their position with respect to money. For all authors, the relationship between the actual means of payment and the corresponding value in 'imaginary money' was crucial. Fixing and so changing that value was a prerogative of monetary sovereignty. Every change in the form of debasement or enhancement affected the entire population, alleviating the burden of debt, especially that of monarchs. But sovereign edicts could be easily contested by merchants and moneychangers. At a time when published texts were rare, the important topic of money was discussed by a great many actors, potentially leading to a diversified range of monetary writings. Meantime, those writings, in the form of treatises, essays or pamphlets gave birth to potentially divergent advice, fuelling both short-term controversies and long-running debate.

\footnotetext{
${ }^{13}$ For Spain, E.J. Hamilton called the beginning of the 18th century the time of monetary 'stability'.
} 
Five categories are considered here. Three of them lay outside the circles of power (2.1), although they were not without influence even so; these were the late scholastics (2.1.1), economic philosophers and polymaths (2.1.2), and pamphleteers (2.1.3). Two categories of commentators moved within the spheres of government, though with very different standpoints: officers of the mint and regular advisers on money (2.1.4) and treasury administrators, fiscal officials, regular advisers on finance, higher officers and ministers (2.1.5).

\subsection{Authors outside the spheres of power}

The logic of publishing led to reprints of works by renowned authors (mostly philosophers), even if their economic doctrines were not their keenest work, while religious doctrines and merchant's writings fuelled discussion about trade. These authors sometimes sought positions of power, and some did manage to move within the circles of power for a more or less extended lapse of time.

\subsubsection{Late scholastics}

Scholastic writings declined progressively after the Renaissance and had almost disappeared by the beginning of the seventeenth century, surviving in Spain alone. Several late scholastics wrote important texts between 1550 and 1600, especially in the school of Salamanca (Grice-Hutchison, 1952; Gómez Camacho, 1998). Typically, they issued confessor's manuals on the ethical and religious implications of the then growing activity of commerce (Azpilcueta and Mercado, both Dominicans). Others wrote on monetary policy from a moral standpoint (Mariana, 1609, a Jesuit, extending his analysis to forceful theoretical considerations). These authors were not connected with sovereigns or government, and their aims were unrelated to any pressing need to secure greater resources or simply a bigger budget for monarch or state. On the contrary, Mariana, who took a rigorous stance on debasement, advocated a modest standard of living for monarchs and fiercely denounced corruption, for which he experienced jail and years of confinement.

Beyond their conception of money as a human convention, the only way to enforce justice was to avoid debasements and to link money to metal. Azpilcueta (1556) and Mercado (1569) formulated ideas relating the value of money to the quantity of it, leading some historians of economic thought to describe them as the true founders of the quantity theory (Baeck, 1988, 1994). They also recognized the benefits of international trade for the whole population, and examined the moneychangers' activities from a moral viewpoint. Some decades later, Mariana (1609) condemned unlimited sovereignty and denounced debasements, in the context of new issues of debased coins made exclusively of copper, prompting the lasting vellón crisis (see de Lozanne Jefferies, 2012). Generally, monetary debasements were seen as falsifications by monarchs, even if circumstances might sometimes justify such manipulations.

In Flanders, the Jesuit Leonardus Lessius (1554-1625) examined the inflow of securities from all over Europe to the Antwerp exchange. As evidence that he monitored the market closely, Lessius published the rates for various European currencies for 7 December 1600 in his treatise De Iustitia et Iure. He examined the market in ethical terms and came up with fresh views on usury (see Van Houdt, 1998).

Scholastics influenced lay writers, especially on usury: Bodin (1576) in France; in England, Malynes (1601) ${ }^{14}$ and Petty (1662), who spent a few years of his youth in a Jesuit college in Caen (Goodacre, 2006); Juan de Lugo in Spain; Seckendorf (1655) in Germany. These writers took an ethical approach. However, it was not necessarily the most recent scholastic ideas that influenced them, and Malynes' denunciation of usury and foreign exchange was a version of the old

\footnotetext{
14 'Of all mercantilists, Malynes is perhaps the one who was influenced the most by Scholastic doctrines.', de Roover, 1974, p. 350.
} 
scholastic condemnation of both practices; by contrast, the Salamanca school analysed and acknowledged market practices. This modern analysis was endorsed by Rebelo (1608), who had been trained in Portugal by masters of the Salamanca school.

\subsubsection{Economic philosophers and polymaths}

A second category comprises economic philosophers and polymaths. In this typology, economic philosophers are scholars known almost exclusively for their contribution to economic and monetary debates, including Montchrestien (1615), who founded the notion of 'political economy' in France (see Clément and Desmedt, 2009) and Genovesi and Galiani in Italy.

Unlike economic philosophers, polymaths were authors whose thinking ranged very widely in scope, embracing the humanities, astronomy or mathematics. Some clearly separated their economic and monetary reflections from their other areas of interest: this was the case of Copernicus around 1520 and Leibniz around 1680 in the Holy Roman Empire, or of Newton around 1710 in England (see below). Others incorporated the economy and money in their philosophical systems: these included Hobbes, Locke and, later, Hume and Berkeley in England; Bodin and Montesquieu in France; Swedenborg in Sweden. These writers might participate in public controversies through the publication of short pamphlets, such as Bodin's (1568) reply to and formal refutation of Malestroit's paradoxes (1566; see Blanc 2007). Similarly, Locke initially published anonymous pamphlets (1691, 1695a) opposing Lowndes' proposal during the recoinage debates. The roles of these thinkers in the economic debates of their time were even more important than their institutional roles. But pamphlets like those of Bodin (1576) and Locke (1695b) have to be considered as a part of a deeper examination of monetary matters. Later, George Berkeley published The Querist (1735-37) to propose monetary and financial solutions to the under-development of Ireland. David Hume, as the British chargé d'affaires in Paris, was involved in the redemption of Canadian paper money (Dimand, 2007). He wrote a memorandum in 1765 defending British holders of French liabilities. As a result, the philosopher tempered his dismissal of paper money issues...

The numerous reprints and translations of the writings of polymaths like Bodin, Hobbes, Locke, Pufendorf and Montesquieu made those prominent thinkers into representatives of a leading current of thought. For example, beyond the clear differences between the theories of sovereignty of Bodin, Mariana and Locke, it is plain that Bodin sought practical limits to the principle of absolute sovereignty in the realm of money, and so was closer than might be suspected to Mariana and Locke's positions on monetary sovereignty. A common concern about the ability to debase the currency led them to vigorously assert the necessity for economic stability as well as for public confidence and, therefore, civil peace. Hence it was important to maintain a metallic system able to prevent any form of 'false' money, generated by individuals or sovereigns (see Blanc and Desmedt 2010).

Accordingly, while authors like Locke may not have been entirely misrepresented by Adam Smith's claim that mercantilists confused wealth and money, in no event should such reasoning be considered a common denominator of 'pre-classical writers'. Within this category of writers, the most highly systematized thought stood clearly apart from mercantilism as it was most commonly characterized.

\subsubsection{Pamphleteers}

Economic philosophers and polymaths sometimes contributed to the public debate by writing pamphlets, but these made up a small if not marginal part of their overall written legacies. There was another category of authors who did not seek to construct any economic and monetary system, but who intervened in economic and monetary issues exclusively through pamphlets, proposing their own analyses and sometimes fresh insights and concepts. In the 
seventeenth-century, 'The pamphlets were efforts at persuasion, designed to appeal to policy makers, and their proliferation in manuscript an printed form is testimony to the increasing complexity of national economic affairs' (Muchmore, 1969, p. 348). Most pamphleteers were very far removed from the centre of power and pointed up one narrow public issue, commonly led by a particular interest groups such as merchants. Many of the pamphlets were directed at very common issues such as debasement, usury, the outflow of good coins, and so on. Some of them made significant analytical and theoretical contributions. In France, Malestroit's text (1566) (written from a position of power) prompted a debate with the publicist Bodin and a string of other writers. Bernardo Davanzati (1588), a merchant in Lyon and then Florence, clearly saw that there were two reasons for money losing its purchasing power: the debasement of specie and the inflow of precious metal from the New World. But the very notion of balance of trade was controversial. For instance, in the debate between Serra and De Santis during the years 16051613 in Naples, the divergence of interpretation was based upon a different definition of the balance of trade: while De Santis enquired why a positive balance did not generate an inflow of currency, Serra (1613) explained that, since movements of capital were included, the balance appeared to be negative. In his "Brief Treatise on the Causes which can make Gold and Silver plentiful in Kingdoms where there are no Mines" Serra believed that gold and silver flowed out of the country to make up the balance of trade deficit, which was worsened by the need to pay interest abroad on the huge public debt (Rosseli, 2000).

In Spain, around the time of the reign of Philip III (1598-1621), the arbitristas proposed original and voluntaristic development schemes. ${ }^{15}$ In England, Mun (1622) and Misselden (1623) presented the concept of balance of trade (Mun supported the interests of the East India Company, Misselden those of the Merchant Adventurers). Later, debates began before the Recoinage Acts with Lowndes's official report (1695) prompting responses from several pamphleteers, including the merchant Barbon (1696), who battled against Locke in vain (see Kelly, 1991).

The disparate character of this category of pamphleteers seems to rule out any systematic presentation of their monetary ideas; no general lesson regarding the view of the economy and money can be drawn from those pamphlets.

A few pamphleteers became temporary advisers briefly moving within the spheres of government. The same was true of polymaths and economic philosophers, although often with greater success. Indeed, gaining influence or gaining admission to the circles of power may well have been the purpose of their public stances in their pamphlets and other monetary writings. Bodin clearly sought an official position, although always unsuccessfully. The one-time Milanese merchant Gerardo Basso became adviser to the Castilian crown; Leibniz was a polymath at one time employed by a ruler as an adviser on monetary matters; Newton was a polymath who became Master of the Mint.

\footnotetext{
15 The arbitrista (opinion giver) in Spain, wrote memoranda for the king, his advisers, and his grand council of state. 'They address themselves to the circumstances experienced by Castile as it fought to survive its own growing weakness, the pressures from the other realms of the empire, and the onslaught against Spanish hegemony spearheaded by France. Against this background the reaction of a sizeable sector of Spanish political opinion was predictably oriented toward revitalizing and strengthening the monarchy's power base.' (Fernandez-Santamaria, 1980, p. 364). Merchants like Luis Valle de la Cerda, Ramón Ezquerra or jurists like Martín González de Cellorigo or Gerardo Basso wielded some influence. The Venetian Jesuit Giovanni Botero (Della ragion di stato, 1589), who resided in Spain, was an exception within this Spanish mainstream.
} 


\subsection{Inside the regime: securing power and stability}

Although the writers in the foregoing categories often attempted to enter the spheres of government, they often remained on the fringes, unlike the next two categories of writers under discussion.

\subsubsection{Officers of the mint and regular advisers on money}

Officers of the mint and regular advisers of sovereign courts on money developed arguments that were far removed from monetary nominalism (the state should define all monetary parameters). They did not analyse monetary issues in order to increase the power of the sovereign, and barely addressed the balance of trade as a means of securing an inflow of currency, although some did associate movements of trade with the quality of the currency.

France's Cour des monnaies is an interesting example. Since 1552, it had played a central role in preparing monetary edicts and it controlled all monetary activity in the kingdom, from the quality of metals to all businesses using money or gold and silver. Through its higher officers, the Cour was a leader of opinion. Its outlook was clearly metallist, in practice if not in theory. ${ }^{16}$ The 1577 reform advocated by Turquam (1578), general officer of the Cour des monnaies, was anything but a 'mercantilist' reform. It was devised to end the dualist monetary system by suppressing the distinction between imaginary and real money: the main existing coin, the $е c u$, was also used as the unit of account. The unit and the coin were then directly defined in metal, and the monarch lost his ability to manipulate money by enhancing the legal price of coins. It went unchanged from 1577 to 1602, when France returned to the dualist monetary system. Turquam's ideas and writings dramatically emphasized the need to anchor money on metal without, however, developing a theoretical framework in which money appeared to be defined as a commodity. No far-seeing theory was to be found in this, neither about money as it related to economic activity, nor about money and the balance of trade; the focus was on urgent currency issues.

In Italy, Scaruffi, director of the Mint of Reggio Emilia, proposed a monetary reform to define coins on the basis of their metallic content alone (Scaruffi, 1582). Montanari (1680) was long employed in organizing and managing the Venitian Mint, the Zecca. From a formal nominalist position (the state defines monetary parameters, whether or not it was metallic money), he identified limits to the freedom of the prince and concluded that money should be defined on the basis of its intrinsic value.

In England, Isaac Newton's position was very interesting in terms of the distinction we draw among the five categories of authors. Before 1694, Newton was not opposed to a devaluation of the English standard ${ }^{17}$; but when he became Master of the Mint, his views were shaped by the interests and the traditional position of that institution, and he began to support the idea of a stable currency. In the early eighteenth century, he validated and institutionalized the Lockean principle of currency stability which had led to the Recoinage Act of 1696 (see Craig, 1963).

In the Holy Roman Empire, Gottfried Leibniz, as just one of his many activities, analysed monetary problems, following his appointment as Librarian and Councillor to the Court of Hanover. He also became technical director of the Harz silver mines. In a series of writings between 1680 and 1692, he elaborated a practical metallist position, estimating that, in the fragmented context of the Empire, the only solution to money was its unification and its centralization on the basis of undisputable metallic currencies, made of pure metal; this would require a voluntary renunciation of any debasement or enhancement by monetary authorities (see Bond, 2012).

\footnotetext{
${ }^{16}$ In Schumpeter's meaning, theoretical metallists consider that metal is the very essence of money, while practical metallists consider that metal is not its essence, but a moral monetary system through a sound currency that is required to anchor its definition in a fixed quantity of precious metal (Schumpeter, 1954).

${ }^{17} \mathrm{He}$ 'recommended a devaluation, and agreed with Lowndes in suggesting one of 20\%', Horsefield, 1960, p.52.
} 
Writings from this category of authors developed mainly during the sixteenth and seventeenth centuries. Then, with the monetary stabilizations of the eighteenth century together with the growing role of paper money, the opinions of masters and other officers of the mint were less sought after.

\subsubsection{Treasury administrators, fiscal officials, regular advisers on finance, higher officers and ministers}

If the category of late scholastics and that of officers of the mint and regular advisers on money reflect outlooks that are markedly different from what might be termed 'mercantilism', this final category exhibits some of the characteristics of Mercantilism "with a capital M" (see below), albeit with substantial nuances. In this category, we find most of the state administrators identified by Schumpeter (1954): people lastingly engaged in state government and administration or permanent advisers. The important figures here were especially in charge of the budget, finance and taxation, but not of money proper. These authors were directly involved in the search for greater power for the monarch or the state, some addressing pressing matters, others long-term issues.

The power of the state is not, however, to be conflated with the financial power of the monarch, which requires the capacity to raise funds through taxes or borrowing, or an abundant treasury. For some of the authors in this category, the efficient circulation of money was the best way to maintain a strong state. This was the case of German cameralist writers (Hörnigk, 1684 and Schröder, 1686; see Bond, 2012), who conceived that money was the best means to obtain wealth rather than a synonym of wealth. As a consequence, the accumulation of currency in the treasury was not the central concern; but its circulation was.

In 1706-07, John Law sent a 'Mémoire' to France's contrôleur des finances proposing a new type of money: the establishment of a land bank in France that would issue notes (a scheme already presented in Law, 1704). This project did not come to fruition, but some years later, Law obtained the Regent's approval and managed the Compagnie d'Occident, founded in August 1717, which later merged with other colonial companies as the Compagnie du Mississippi. Law's idea was to convert public rents into shares in the Compagnie, and to transform the company's shares into a new type of currency (Murphy, 1997). The bubble burst and the system collapsed in 1720.

Money appeared to be, at first, a product of the state, controlled by the monarch by law. This chartalism was affirmed for example in Italy by the Napolitan Santis (1605), in Germany by the cameralists Seckendorf (1655) and Hörnigk (1684), and in England by Lowndes (1695). In the Holy Roman Empire, which was highly fragmented among local sovereign territories, chartalism was frequently associated with proposals to simplify and centralize the issuing of money (see Seckendorf). Anyway, this formal chartalism was sometimes masked by a practical metallism devised to ground the sovereign's power more firmly, especially during times of crisis. Some of these writers did identify wealth with money, but the notion was not a prominent one; it seems rather to have been a common idea among lesser authorities on the question, who were not out to constuct a theoretical framework and who were not generally called upon to advise rulers at all (especially numismatists such as Bouteroue, 1666, in France).

A favourable balance of trade was a key feature of the ideas of this group of authors. It was a widely shared proposal that there should be some control, or tighter control, of imports, especially limiting or prohibiting specific kinds of imports, particularly of luxury goods. It was less commonly suggested that exports should be stimulated, notwithstanding the policies of ministers like Laffemas (1602) and Colbert (in office from 1665 to 1683) in France and, after Colbert, among German cameralists like Hörnigk. 
Plainly this final category of writers developed views that were very remote from the ethical concerns of the late scholastics. While the latter concentrated on the moral issues of the operations under study, the treasury officials were primarily concerned with the beneficial character for the regime of the matters under debate. ${ }^{18}$ Sometimes, the narrowness of perspective of these state officials acted as a base on which classical Whiggism could anchor its repudiation of the writers of the former age as a whole.

\section{Concluding remarks}

We repeat that the deconstruction undertaken here does not aim to demonstrate that preclassical writings were devoid of any conceptualization or internal coherence. However, contemporary readers must make some effort to grasp the concepts used and engage with the proposals made. To this end it might be useful to propose an initial classification of authors based on their social position.

Writings about monetary matters from the sixteenth to the eighteenth centuries had frequently been described as analytical fallacies, being 'pre-', whether Smithian, Classical or modern. They were instrumentalized whether to vindicate political decisions, or to demonstrate theoretical inconsistency. But Locke's or the cameralists' views were hardly representative of all monetary doctrines during this vast period. This is an obvious call to deconstruct the 'Mercantilist' notion "with a capital "M"". ${ }^{19}$ It should be recognized that common denunciations did not lead to common theories or, at least, to a wide range of commonly shared analyses. Moreover, there were different sorts of writings with different goals, which were translated into divergent political and sometimes theoretical positions. Finally, 'mercantilist' ideas were hardly to be found in the writings of scholastics, regular advisors on money, administrators of the mint and philosophers although they may have been advocated by administrators of the treasury, tax officials, regular advisers on budgets, higher officials and ministers, and of a string of pamphleteers. All this demonstrates how limiting it has been to represent mercantilism as a universal ideology of the times.

Reading the history of economic thought as a process leading to improvement, that is, drawing a line between 'pre-scientific' and 'scientific' discourse (Stigler), or pointing up the 'fallacies' (Viner) of pre-classical writers, can be characterized as Whiggism in this domain. Readers who discard this approach and attempt to understand a small part of the impressive number of analyses of wealth, trade or money published before 1776 will be amazed by the diversity and depth of these 'monetary cranks' lost in the 'crude fancy of childhood'.

\section{BIBLIOGRAPHY}

\section{Primary sources}

Azpilcueta M., 1556, Comentario resolutorio de cambios, Madrid, 1965.

Barbon N., 1696 A Discourse Concerning Coining the New Money Lighter, London.

Berkeley, G., 1735-1737 \& 1750, The Querist, in The Works of George Berkeley, ed. By A. Luce, T. Jessop, vol.6, pp.101-181, Nelson and Co, London.

Bodin, J., 1568, "La response de Maistre Jean Bodin advocat en la Cour au Paradoxe de Monsieur de Malestroit, touchant l'encherissement de toutes choses, et les moyens d'y remedier", in Le

\footnotetext{
${ }^{18}$ For Spain, for example, 'Contrary to the doctores of Salamanca, with their ethical point of view, Botero expressed secularized ideas on the running of a modern nation and on the development of its productive capacity', Baeck, 1994, p. 189

19 This expression is from Appleby, see Winch, 1985, p. 288.
} 
Branchu (ed.), Ecrits notables sur la monnaie (XVIe siècle). De Copernic à Davanzati, volume 1, Paris: Alcan, 1934, pp. 69-177.

----, 1593 [1576], Les six livres de La République, 6 volumes, Paris: Fayard, 1986.

Bouterouë, C., 1666, Recherches curieuses des monoyes de France depuis le commencement de la monarchie, Paris: Cramoizy.

Davanzati, B., 1588 (1988) Lezione delle Monete e Notizia de' Cambj, Turin : Fogola editore.

De Santis, M.-A., 1605a, Discorso intorno alli effetti che fa il cambio in regno, in: Colapietra (Raffaele), a cura di: Problemi monetari negli scrittori napoletani del Seicento, Rome: Accademia Nazionale dei Lincei, 1973, pp. 111-141.

----, 1605b, Secondo discorso intorno agli effetti che fa il cambio in regno, in Colapietra, Problemi monetari negli scrittori napoletani del Seicento, Rome: Accademia Nazionale dei Lincei, 1973, pp. 143-162.

Hörnigk (von), W., 1684, Oesterreich über alles, Wann es nur will, Schäffer-Poeschel Verlag, Stuttgart, 1997

Laffemas de, B. de, 1602, Comme l'on doibt permettre la liberté du transport de l'or et de l'argent hors du royaume, Paris.

Law J., 1704, Essay on a land bank, A. Murphy ed., 1994, Dublin: Aeon Publishers.

Locke, J., 1691, Some Considerations of the Consequences of the Lowering of Interest, and Raising the Value of Money, 2nd ed., 1696, A.M. Kelley, New York, 1968.

----, 1695a, Short Observations on a Printed Paper intituled, For encouraging the Coining Silver Money in England, and after for keeping it here, A.M. Kelley, New York, 1968.

----, 1695b, Further Considerations concerning Raising the V alue of Money, A.M. Kelley, New York, 1968.

Lowndes W., 1695, A Report Containing an Essay for the Amendment of the Silver Coins, London

Malestroit, J. Ch. de, 1566, "Les paradoxes du seigneur de Malestroict, Conseiller du Roi et maistre ordinaire de ses comptes, sur le faict des monnoyes présentez a sa majesté, au mois de mars, MDLXVI", in Le Branchu (ed.), Ecrits notables sur la monnaie, vol. 1, Paris: Félix Alcan, 1934, pp. 49-68.

Malynes, G., 1601, The Canker of Englands Commonwealth, London.

Malynes, G., 1623, The Center of the Circle of Commerce, A.M. Kelley, 1973, Clifton.

Mariana, J. de, 1609. "A treatise on the alteration of money", Journal of Markets and Morality, 5:2, 2002, pp. 523-93.

Mercado, T. de, 1569, Suma de tratos y contratos, Madrid: Instituto de Estudios Fiscales, 1977.

Mirabeau, 1763, Philosophie Rurale ou Economie générale et politique de l'Agriculture, Amsterdam.

Misselden, E., 1623, The Circle of Commerce or the Ballance of Trade, A.M. Kelley, New York, 1971.

Montanari G., 1680, Breve trattato del valore delle monete in tutti gli stati (1680), in Custodi, Scrittori classici italiani di economia politica, Roma, 1965.

Montchrestien, A. de, 1615, L'économie politique patronale. Traicté de l'oeconomie politique, Paris: Plon, 1889.

Mun, T., 1664, England's Treasure by Forraign Trade, MacMillan, New York, 1895.

Petty, W., 1662, Treatise of Taxes and Contributions, in: The Economic Writings of Sir William Petty, C.H. Hull éd., 1899, A.M. Kelley, Fairfield, 1986, pp.3-97.

Rebelo, F., 1608, "Tratado do Câmbio", in Rau, Estudos sobre História Económica e Social do Antigo Regime, Lisbonne : Editorial Presença, 1984, pp. 83-129.

Scaruffi G., 1582, L'Alitinonfo, Per Fare Ragione, Et Concordanza D'Oro, E D'Argento, in Augusto Graziani Economisti del cinque e seicento, Laterza \& figli Tipografi, 1913.

Schröder, W., 1686, Fürstliche Schatz- und Rent-Cammer, Leipzig.

Serra, A., 1613, Breve trattato delle cause che possono far abbondare li regni d'oro e argento dove non sono miniere con applicazione al Regno di Napoli, in Colapietra, Problemi monetari negli scrittori napoletani del Seicento, Rome: Accademia Nazionale dei Lincei, 1973, pp. 163-228.

Seckendorff (von), L., 1655, Teutscher Fürsten-Stat, Glashütten/Taunus 1976.

Turquam, Th., 1578, Advis de M. Thomas Turquam... afin d'abolir le compte à sols et à livres. Paris: Dalier et Roffet.

\section{Other references}

Aglietta, M., 2002, "Whence and Whither Money?”, in: OECD, The Future of Money, Paris: OECD, pp.3172.

Appleby, J.O., 1978a, Modernization Theory and the Formation of Modern Social Theories in England and America", Comparative Studies in Society and History, Vol. 20, No. 2, pp. 259-285

Appleby, J.O., 1978b, Economic Thought and Ideology in Seventeenth-Century England, Princeton University Press.

Backhaus, J.G., 2004, Joseph A. Schumpeter's contributions in the area of fiscal sociology: a first 
approximation', Journal of Evolutionary Economics, Vol. 14, 2, pp.143-151

Baeck, L., 1988, "Spanish economic thought: the school of Salamanca and the arbitristas", History of Political Economy, vol.20, 3, pp.381-408

Baeck, L., 1994, The Mediterranean Tradition in Economic Thought, Londres: Routledge

Blanc J., 2007, "Beyond the quantity theory. A reappraisal of Jean Bodin's monetary ideas", in: Giacomin and Marcuzzo (Eds.), Money and Markets. A Doctrinal Approach, London, New York: Routledge, pp. 135-149.

Blanc J., Desmedt, L., 2010, « Counteracting counterfeiting? Bodin, Mariana and Locke on False Money as a Multidimensional Issue", History of Political Economy, vol.42, 2, pp.323-360

Blaug, M., 1964, "Economic Thought and Economic History in Britain, 1650-1776", Past and Present, 28, pp.111-116.

Blaug, M., 2001, "No history of ideas, please, we're economists", Journal of Economic Perspectives, Vol. 15, 1, pp.145-164

Bond N., 2012, "La monnaie et le monstre : parfums pécuniaires dans le Saint Empire romain germanique du seizième au dix-septième siècle", in: J. Blanc and L. Desmedt, Les pensées monétaires dans l'bistoire, 1517-1776.

Brewer, J., 1989, The sinews of power: War, money, and the English state, 1688-1783, Taylor and Francis, London.

Clément, A., Desmedt, L., 2009, "Medicine and economics in pre-classical writings", in: Open Economics: Economics in relation to other disciplines, R. Arena et S. Dow, M. Klaes eds, Routledge, London, pp.108-125.

Coats A. W. B, 1992, On the History of Economic Thought. British and American Economic Essays, London: Routledge

Coleman D.C., 1957. "Eli Heckscher and the Idea of Mercantilism", Scandinavian Economic History Review, $\mathrm{V}(1)$, pp. 3-25.

Coleman D. C. (ed.), 1969, Revisions in Mercantilism, London: Methuen.

Coleman D. C., 1980, "Mercantilism Revisited", The Historical Journal, 23, no 4, pp. 773-791.

Craig J., 1963, "Isaac Newton and the counterfeiters", Notes and Records of the Royal Society of London, 18, 2, pp.136-145.

Cunnigham, W., 1903 (third ed.), The Growth of English Industry and Commerce, T.I., The mercantile system, Cambridge: Cambridge University Press.

de Lozanne Jefferies C., 2012, "Monetary Theory and Monetary Policy in Castile during the first half of the 17th Century", to be published in: J. Blanc and L. Desmedt (eds), Les pensées monétaires dans l'bistoire, 1517-1776.

de Roover, R., 1955, "Scholastic Economics: Survival and Lasting Influence from the Sixteenth Century to Adam Smith", The Quarterly Journal of Economics, Vol. 69, No. 2 (May, 1955), pp. 161-190.

de Roover, R., 1974, "Gerard de Malynes as an Economic Writer: From Scholasticism to Mercantilism", in: Business, banking, and economic thought in late medieval and early modern Europe: Selected studies of Raymond de Roover, J. Kirshner éd., Chicago: Chicago University Press, pp.346-366.

Dickson, P. G. M. 1967, The Financial Revolution in England. London: Macmillan

Dimand R., 2007, "David Hume on Canadian Paper Money", in David Hume's Political Economy, C. Wennerlind and M. Schabas eds, Routledge, pp.168-179

Ekelund, R.B., Tollison, R.D., 1997, Politicized Economies. Monarchy, Monopoly, and Mercantilism, College Station: Texas University Press.

Fernández-Santamaria, J.-A., 1980, "Reason of State and Statecraft in Spain (1595-1640)", Journal of the History of Ideas, Vol. 41, 3, pp. 355-379

Finkelstein, A., 2000. Harmony and the Balance: An Intellectual History of Seventeenth-Century English Economic Thought, Ann Arbor: University of Michigan Press.

Gerschenkron A., 1969, "History of Economic Doctrines and Economic History", American Economic Review, vol.59, 2, pp.1-17.

Gómez Camacho, F. 1998, "Later Scholastics: Spanish Economic Thought in the Sixteenth and Seventeenth Centuries", in Ancient and Medieaval Economic Ideas and Concepts of Social Justice, ed. by S. Todd Lowry and B. Gordon. Leiden: Brill, pp.503-561.

Goodacre, H., 2006, "French Jesuits, English political economy, and a 'most remarkable accident", 10th Annual Conference of the European Society for the History of Economic Thought, Porto, April 2006.

Grice-Hutchison, M., 1952, The School of Salamanca, Clarendon Press, Oxford

Heaton, H., 1937, “Heckscher on mercantilism”, Journal of Political Economy, 45, pp.370-393 
Heckscher, E.F., (1931) 1935, Mercantilism, Allen and Unwin, London

Heckscher, E.F., 1936, «Mercantilism », in « Revisions in Economic History », Economic History Review, vol. VII, pp.44-54

Herlitz, L., 1964, "The concept of Mercantilism", The Scandinavian Economic History Review, XII, 2, pp.101120, reprinted in Early Mercantilists, M. Blaug ed., pp.127-146.

Hettne B., 1993, "The concept of neomercantilism", in: Lars Magnusson (Ed.), Mercantilist Economics, Recent Economic Thought, Boston, Dordrecht, London: Kluwer Academic Publishers, pp. 235255.

Hont I., 2005, Jealousy of Trade. International competition and the Nation-state in historical perspective, Cambridge (MA), London: Harvard University Press.

Horsefield, J.K., 1960, British Monetary Experiments, 1650-1710, Harvard University Press, Cambridge Mass.

Hunt, E.K., Lautzenheiser, M., 2011, History of Economic Thought, a critical perspective, M.E. Sharpe

Hutchison, T., 1988, Before Adam Smith, the emergence of political economy, 1662-1776, Blackwell, Oxford.

Judges, A.V., 1939, "The Idea of a Mercantile State", Transactions of the Royal Historical Society, XXI, pp.4169

Kelly, P.H., 1991, 'General Introduction', in Locke on Money, Clarendon Press, Oxford, vol.I, pp.1-121

Keynes, J. M., 1936, The General Theory of Employment, Interest and Money, Londres, Macmillan; in Collected Writings, VII, 1973

Kurz, H.D., 2006, "Whither the history of economic thought? Going nowhere rather slowly?", The European Journal of the History of Economic Thought, vol.13, 4, pp.463-488

Magnusson Lars (ed.), 1993, Mercantilist Economics. Recent Economic Thought, Boston, Dordrecht, London: Kluwer Academic Publishers.

Magnusson Lars, 1994, Mercantilism : the Shaping of an Economic Language, London: Routledge.

Mill, J.S., 1848-1871, Principles of Political Economy, ed. by J.M. Robson, 2 vols, University of Toronton Press, 1968.

Mirowski, P., 1989, More heat than light, Cambridge University Press, Cambridge.

Muchmore, L., 1969, "Gerrard de Malynes and Mercantile Economics", History of Political Economy, 1, pp.336-358.

Murphy A. E., 1997, John Law Economic Theorist and Policy-Maker, Oxford : Oxford University Press and Clarendon Press.

O'Brien, P.K., 1988. "The Political Economy of British Taxation, 1660-1815", The Economic History Review, Vol. 41, 1, pp. 1-32

Perrotta C., 2004, Consumption as Investment: I. The Fear of Goods from Hesiod to Adam Smith, London and New York: Routledge.

Pocock, J. G. A., 1975, The Machiavellian Moment: Florentine Political Thought and the Atlantic Republican Tradition, Princeton: Princeton University Press.

Polanyi K., 1944, The Great Transformation: The Political and Economic Origins of Our Time, New York, Toronto : Farrar \& Rinehart.

Rashid, S., 1993, 'Mercantilism: A Rent-seeking Society?', in Magnusson (ed.) 1993.

Rosselli A., 2000, "Early Views on Monetary Policy: The Neapolitan Debate on the Theory of Exchange History of Political Economy", History of Political Economy, 32(1), pp. 61-82.

Root, H. L. 1994. The Fountain of Privilege: Political Foundations of Markets in Old Regime France

and England. Berkeley: University of California Press.

Schmoller, G., 1897, The Mercantile System and its Historical Significance, N.Y.: MacMillan, 2nd ed., 1910.

Schumpeter, J.A., 1954, History of Economic Analysis, Allen \& Unwin, 1961.

Skinner, Q., 1965, « History and Ideology in the English Revolution », The Historical Journal, vol.8, 2, pp. $151-178$

Smith, A., 1762-63, Lectures on Jurisprudence, ed. by R.L. Meek, D.D. Raphael, P.G. Stein, 1978, Clarendon press, Oxford.

Smith, A., 1776, An Inquiry into the Nature and Causes of the Wealth of Nations, ed. by R.H. Campbell and A.S. Skinner, 1979, Clarendon press, Oxford.

Stigler, G., 1983, "Nobel Lecture: The Process and Progress of Economics", Journal of Political Economy, vol.91, 4, pp.529-545.

Tamura S., 2001, "Gustav von Schmoller and Werner Sombart: A contrast in the historico-ethical method and social policy", in: Yukichi Shionoya (Ed.), The German Historical School: The Historical and Ethical Approach to Economics, New York: Routledge, pp. 105-119. 
Van Houdt, T., 1998, 'Lack of money': a reappraisal of Lessius' contribution to the scholastic analysis of money-lending and interest-taking', The European Journal of the History of Economic Thought, Vol 5, 1, pp. $1-35$

Vickers, D., 1960, Studies in the Theory of Money 1690-1776, Peter Owen Ltd, London.

Viner, J., 1930a, "English Theories of Foreign Trade Before Adam Smith", Journal of Political Economy, Vol. 38, 3, pp. 249-301.

Viner, J., 1930b, "English Theories of Foreign Trade Before Adam Smith (Concluded)", Journal of Political Economy, Vol. 38, 4, pp. 404-457.

Viner, J., 1937, Studies in the Theory of International Trade, Harper, New York.

Wilson, C., 1957, "Mercantilism: Some vicissitudes of an idea", The Economic History Review, X, 2, pp.181188.

Wilson, C.H., 1967, "Trade, Society and the State", in The Cambridge Economic History of Europe, T.IV, Cambridge University Press, Cambridge, pp.487-575.

Winch, D., 1985, "Economic liberalism as ideology: The Appleby version", Economic History Review, vol.38, 2, pp.287-297. 